\title{
Explaining the willingness of public professionals to implement new policies: a policy alienation framework
}

\author{
Lars Tummers
}

This is the last version of the submitted manuscript, which has been published in the International Review of Administrative Sciences (IRAS):

Tummers, L.G. (2011). Explaining the willingness of public professionals to implement new policies: A policy alienation framework. International Review of Administrative Sciences, 77(3), 555-581.

DOI: $10.1177 / 0020852311407364$

The author would like to thank prof. dr. Bram Steijn, prof. dr. Victor Bekkers, dr. Sandra van Thiel, Peter Niesink, mr. Rein Baneke and the two anonymous reviewers for their constructive comments on earlier versions of this article.

\author{
Lars Tummers \\ Dept. of Public Administration \\ Erasmus University Rotterdam \\ P.O. Box 1738 \\ NL-3000 DR Rotterdam \\ Tummers@fsw.eur.nl \\ Also affiliated to PwC (PricewaterhouseCoopers) Advisory, Healthcare
}




\begin{abstract}
Nowadays, many public policies focus on economic values, such as efficiency and client choice. Public professionals often show resistance to implementing such policies. We analyse this problem using an interdisciplinary approach. From public administration, we draw on the policy alienation concept, which consists of five dimensions: strategic powerlessness, tactical powerlessness, operational powerlessness, societal meaninglessness and client meaninglessness. These are considered as factors that influence the willingness of professionals to implement policies (change willingness - a concept drawn from the change management literature). We test this model in a survey among 478 Dutch healthcare professionals implementing a new reimbursement policy. The first finding was that perceived autonomy (operational powerlessness) significantly influenced change willingness, whereas strategic and tactical powerlessness were not found to be significant. Second, both the meaninglessness dimensions proved highly significant. We conclude that clarifying the value of a policy is important in getting professionals to willingly implement a policy, whereas their participation on the strategic or tactical levels seems less of a motivational factor. These insights help in understanding why public professionals embrace or resist the implementation of particular policies.
\end{abstract}

\title{
Points for practitioners
}

Policymakers develop public policies which, nowadays, tend to focus strongly on economic values, such as increasing efficiency or offering citizens the opportunity to choose among suppliers of public services. Public professionals, who have to implement these policies, are often reluctant so to do. This study shows that the causes of this resistance are unlikely to be found in the lack of influence these professionals have in the shaping of the policy at the national or organizational level. Rather, professionals might resist implementing policies because they do not see them as meaningful for society, or for their own clients. Therefore, policymakers should focus on this perceived meaninglessness and adopt ways to counter this, for example by intensively communicating the value associated with a policy.

Keywords

1. Change Management

2. Policy alienation

3. Policy implementation

4. Public professionals

5. Resistance to change 


\section{Introduction}

This article examines factors that influence the willingness of public professionals to implement new policies using a quantitative, survey-based approach. In doing this, we combine insights from public administration literature (Freidson, 2001; Lipsky, 1980; Tummers et al., 2009) and change management literature (Metselaar, 1997; Piderit, 2000).

In public administration literature, there is an intense debate concerning the pressures public professionals face in service delivery (Ackroyd et al., 2007; De Ruyter et al., 2008; Exworthy \& Halford, 1998; Noordegraaf \& Steijn, forthcoming 2011). This debate often focuses on the pressures professionals face when implementing new policies (Duyvendak et al., 2006; Freidson, 2001). Researchers note that many contemporary policies focus strongly on economic values, such as efficiency and client choice. This can be seen as an outcome of the influence of New Public Management (NPM) (Hood, 1991). Public professionals may have difficulty in accepting the changing trade-offs in values which become manifest when implementing such a policy programme. Here, Emery and Giauque (2003:475) note that 'to focus on only the economic logic of action poses problems for public agents. They have to set aside some other shared values in order to concentrate solely on "measurement management"'. These adopted output performance norms often conflict with professional standards, or with the demands of increasingly empowered clients. As a result, public professionals often seem to be unwilling to implement new policies.

Examples of this unwillingness abound (Duyvendak et al., 2006; Freidson, 2001). For instance, in the Netherlands, many insurance doctors encountered substantial professional and moral concerns when asked to implement a new policy focused on re-examining welfare clients (De Boer \& Steenbeek, 2005). Other examples from Canada show that public professionals often do not accept new policies, and sometimes therefore leave and start their own organizations (White, 1996).

Thus, in the public administration literature, there are indications of professionals being unwilling to implement new policies. Change management literature has a long history of examining - both qualitatively and quantitatively - the willingness of employees to accept or reject changes. The support for organizational change on the part of employees is generally viewed as critical for the success of planned changes. As such, much attention is focused on better understanding the ways in which employees' responses to change are shaped (Piderit, 2000).

In this article, we explicitly choose an interdisciplinary approach, combining insights from both the public administration and the change management literature streams. Our main goal is to quantitatively examine those factors that influence the willingness of public professionals to implement new policies. In this, we use the concept of change willingness 
(Metselaar, 1997) as a dependent variable. From public administration research, we draw on the policy alienation concept that consists of five dimensions: strategic powerlessness, tactical powerlessness, operational powerlessness, societal meaninglessness and client meaninglessness (Tummers et al., 2009). We test the relationships between these five dimensions and change willingness in a survey involving 478 Dutch psychiatrists, psychologists and psychotherapists implementing a new reimbursement policy.

The first contribution made by this article will be to the public administration literature on the experiences of public professionals with NPM. This field has often been characterised by qualitative research (for example Ackroyd et al., 2007; De Ruyter et al., 2008; Thomas \& Davies, 2005), and only a limited number of studies use quantitative approaches. A notable exception is the work by some Norwegian academics (for instance Christensen \& Laegreid, 2008). One of the strengths of qualitative research is that it can capture process-related features which are very relevant for studies on NPM and change. In general, quantitative research can help in hypothesis testing and statistical generalization. Quantitatively analyzing important research questions - such as the relationship between discretion and NPM (Brodkin, 2007) - can yield new insights, thereby adding to the debate. For instance, do many professionals really sense insufficient discretion when implementing NPM-like policies, as some authors claim (Van den Brink et al., 2006), or is the opposite closer to the truth: that NPM 'underlined the need for decentralized decision-making and autonomy, which can be seen as favouring professionals' (Brandsen, 2009:263)? A quantitative approach can test existing relationships and thereby provide new insights to the debate concerning the experiences of NPM at the 'street-level', where policies are implemented.

The second contribution is to the change management literature concerning the public sector. Change management literature includes reviews of several aspects, including restructuring, reengineering, the introduction of new technology and Total Quality Management (Burke \& Litwin, 1992). However, little attention has been given to the way in which public employees react to new public policies. This reflects the perception that most literature on organizational change and innovation has concentrated on major changes that affect private sector organizations (Kickert, forthcoming 2011). In this article, we look specifically at the experiences of public professionals when dealing with public policies, and thus draw on concepts from the public administration literature which fit this context.

This brings us to the outline of this article. In Section 2, we develop a theoretical framework and end the section with hypotheses concerning factors that may influence change willingness. In Section 3, the method established for testing these hypotheses is outlined. The results of the subsequent survey - including hypothesis testing - are shown in Section 4 . We conclude by discussing the contribution of this article to the public 
administration literature and to the change management literature concerning the public sector.

\section{Theoretical framework}

This section firstly provides a background on the study of professionals and their experiences with NPM. Next, we will review insights from the change management literature, focusing on the concept of change willingness. Third, we will introduce the policy alienation concept. We will then connect change willingness and policy alienation, resulting in five hypotheses.

\subsection{Background: professions, professionalism and NPM}

The concept of profession is a contested one (Eraut, 1994; Evetts, 2003). A number of scholars (such as Parsons, 1964) have attempted to list a number of defining characteristics which distinguish professions from non-professions. However, others have noted that there is no general consensus about these defining characteristics and, instead, have offered a list of relevant occupational groups, such as medical specialists and lawyers (Abbott, 1988; Hanlon, 1998).

Closely related to the contested concept of profession is 'professionalism'. Durkheim (1992) saw professionalism as a form of moral community based on occupational membership. Eraut (1994) treats professionalism as an ideology embodying values such as integrity and autonomy. By looking at the content of the work, Schön (1983) observed that professionalism can be defined using what he calls the 'model of technical rationality' (Noordegraaf, 2007). Viewed in this light, professionalism is about applying general, scientific knowledge to particular cases in a rigorous, routine way (Abbott, 1988; Freidson, 1994). Hence, different conceptualizations of professions and professionalism seem to co-exist.

In contemporary society - including the public sector - the concepts of profession and professionalism are still debated and remain highly relevant. Alongside traditional professions such as medicine and law, other occupations try to 'professionalize' themselves such as managers (Van Bockel \& Noordegraaf, 2006) and consultants (Alvesson \& Johansson, 2002). For the workers themselves, such professionalization can be beneficial, for example by establishing occupational closure, that is closing off entry to everyone apart from those suitably qualified (Abbott, 1988). Alongside these 'internal' demands, groups outside the occupation also stimulate professionalization, for instance when they demand 'evidence-based' knowledge.

However, at the same time, professions have to face numerous pressures which contradict the ideals of professionalism. These pressures can come from various sources, such as changes in their organizations, and in economic or political viewpoints. As a result, some professions are thought to be experiencing a reduction in their autonomy and 
dominance (Evetts, 2003:369). In a similar vein, Krause (1996) argued, based on a large comparative study, that professions were experiencing a decline in their power relative to that of state and capitalist institutions.

In public domains, an important source of pressure on professionalism is the introduction of 'New Public Management' (Hood, 1991; Pollitt \& Bouckaert, 2004). NPM focuses on business-like values, such as efficiency, transparency and client choice. As noted in the introduction, professionals might see it as problematic if these values dominate over traditional professional values such as autonomy and equity. These changing contexts can affect and constrain professional work (Noordegraaf, 2007).

However, it would be unwarranted to claim that NPM is viewed as negative for all professions under all circumstances. For instance, Noordegraaf (2007:763) notes that 'these very same evidence-based and outcome-oriented movements are also used to professionalize quasi-, proto- or semi- professional occupations, such as social work and nursing'. Hence, the relationship between New Public Management and professionals is more complex than a simple 'clash of cultures' between managerialism and professionalism (cf. Raelin, 1986).

The discussion above provides us with a background for the research problem assessed in this article, showing the context in which the implementation by public professionals of NPM policies nowadays takes place. As NPM is not by definition welcomed by professionals, it seems important to examine the ways in which professionals react to its introduction. Change management explicitly examines the way changes - in this case a NPM policy - are assessed by workers in an organization. We therefore now look at the change management literature, and relate it to insights from the sociology of professions literature.

\subsection{Change management and change willingness}

Early change management theories were based on the assumption that organizational change can be successfully planned by change managers. These are referred to as 'planned change' theories, and are often based on the seminal work of Lewin (1951). Lewin conceptualized change as progressing through successive phases labelled unfreezing, moving and refreezing. Building on this early work, others have described multi-phase models that change agents can follow in implementing changes (see Judson, 1991).

The planned change approach dominated the theory and practice of change management until the early 1980s. Since then, an 'emergent' change approach has become more prominent (Kickert, forthcoming 2011). The emergent change approach does not consider change as a linear process, or an isolated event, but sees change as continuous, recursive and unpredictable. Change appears to be unplanned and unexpected (Weick, 2000). That is, 
there is no deliberate orchestration of change, no dramatic discontinuity and no definitive steps in the change.

Although the planned and the emergent change approaches differ considerably, they both stress that willingness to implement a change by employees is crucial. Metselaar (1997:42) defines this change willingness as 'a positive behavioural intention towards the implementation of modifications in an organization's structure, or work and administrative processes, resulting in efforts from the organization member's side to support or enhance the change process.' According to planned change theories, an absence of willingness would result in top management's intentions to instil a change not being transformed into real change efforts by lower echelons (Judson, 1991). According to this emergent school, unwillingness would impede the process of endless modifications, which would no longer accumulate and amplify. Indeed, throughout change management history is has been fairly unambiguously claimed that a crucial condition for success is that employees are willing to implement the change (Higgs \& Rowland, 2005; Judson, 1991).

When we relate the study of professions to change willingness - or rather resistance to change - we note that resistance can sometimes be understood as a way to counter attacks on the profession. For example, when a new change confronts the exclusive rights to insist on a specific education and to select only occupational members (in essence a measure countering occupational closure), professionals may for these very reasons oppose the change. When this happens, the discourse on professionalism can be used by the occupational groups as an instrument to counter occupational change and social control (Evetts, 2006:141). In this article, we use the concept of change willingness to examine the willingness of public professionals to implement a particular NPM policy.

\subsection{Policy alienation}

For factors that possibly influence change willingness, we turn to the dimensions of a concept taken from public administration research: policy alienation. Policy alienation is defined as a general cognitive state of psychological disconnection from the policy programme being implemented, in this instance by a public professional who regularly interacts directly with clients (Tummers et al., 2009). First, we will give a short overview of the background to alienation.

Alienation broadly refers to a sense of social estrangement, an absence of social support or meaningful social connection. Its use in scientific literature can be traced directly to Hegel and Marx, who both saw capitalism as the main cause of alienation. Sociologists, public administration scholars and other social scientists have since used the alienation concept in various studies. As a result, a number of meanings have been attributed to the term (Kanungo, 1982:24). In an attempt to provide clarity, Seeman (1959) - in a landmark 
article - broke these meanings down into five alienation dimensions: powerlessness, meaninglessness, normlessness, social isolation and self-estrangement. Given that there is no theoretical structure linking the five dimensions and that the presence of all the dimensions is not required, scholars are effectively free to choose which dimensions best fit their research context (Rayce et al., 2008).

Many scholars have used such classifications to devise operational measures for alienation so that they can examine the concept in diverse settings. Rayce et al. (2008), when investigating adolescent alienation, used three of the five dimensions. Further, researchers have used Seeman's classification to examine work alienation (such as Blauner, 1964). In this article, we use Seeman's classification for examining the policy alienation concept.

How can the concept of alienation be linked to the world of policy implementation? Public policies refer to the binding allocation of values, for society as a whole, in a situation of structural scarcity due, for example, to a lack of financial or natural resources (Easton, 1965). As a result, trade-offs occur between these values, for example between efficiency and equity (Stone, 2003). This is why street-level public servants are sometimes able to make their own judgements on an appropriate trade-off when applying a policy to an individual case, such as when a police officer decides whether to impose an on-the-spot fine (Lipsky, 1980). When professional case workers have to implement a policy, many such trade-off situations will arise. These public professionals, as members of professional communities or associations, also have to accommodate professional norms and standards.

Policy alienation is multidimensional, consisting of powerlessness and meaninglessness dimensions (for a more elaborate explanation, see Tummers, 2009). In essence, powerlessness is a person's lack of control over events in their life. Meaninglessness, on the other hand, is the inability to comprehend the relationship of one's contribution with a larger purpose. Professionals can feel powerless while implementing a policy, for example if they have no influence over the sort, quantity and quality of sanctions and rewards they issue (Lipsky, 1980). Further, it is also evident that professionals can feel that implementing a policy is meaningless, if, for example, it does not deliver any apparent beneficial outcomes for society (Van Thiel \& Leeuw, 2002). To make the dimensions more specific to the situation being studied, we distinguish between strategic, tactical and operational powerlessness, and between societal and client meaninglessness. The definitions of these dimensions are shown in Table 1 below. 
Table 1 Operationalization of policy alienation: Five dimensions

\begin{tabular}{|c|c|c|}
\hline Dimension & Definition & An example situation leading to a high score \\
\hline $\begin{array}{l}\text { Strategic } \\
\text { powerlessness }\end{array}$ & $\begin{array}{l}\text { The perceived influence of the professionals on } \\
\text { decisions concerning the content of the policy, as is } \\
\text { captured in rules and regulations. }\end{array}$ & $\begin{array}{l}\text { A professional feeling that the policy is drafted } \\
\text { without the help of implementing professionals or } \\
\text { professional associations. }\end{array}$ \\
\hline $\begin{array}{l}\text { Tactical } \\
\text { powerlessness }\end{array}$ & $\begin{array}{l}\text { The professionals' perceived influence on decisions } \\
\text { concerning the way policy is implemented within their } \\
\text { own organisation. }\end{array}$ & $\begin{array}{l}\text { Professionals stating that the managers in the } \\
\text { organization did not consult them or their colleagues } \\
\text { when designing the implementation process for the } \\
\text { policy. }\end{array}$ \\
\hline $\begin{array}{l}\text { Operational } \\
\text { powerlessness }\end{array}$ & $\begin{array}{l}\text { The perceived degree of freedom in making choices } \\
\text { concerning the sort, quantity and quality of sanctions } \\
\text { and rewards on offer when implementing the policy. }\end{array}$ & $\begin{array}{l}\text { Answering 'fully agree' to a survey question on } \\
\text { whether the professional feels that their autonomy } \\
\text { during the implementation process was lower than it } \\
\text { should be. }\end{array}$ \\
\hline $\begin{array}{l}\text { Societal } \\
\text { meaninglessness }\end{array}$ & $\begin{array}{l}\text { The perception of professionals concerning the } \\
\text { added value of the policy to socially relevant goals. }\end{array}$ & $\begin{array}{l}\text { Stating in an interview that "I agree with the policy } \\
\text { goal of enhancing transparency, but I do not see how } \\
\text { this policy helps in achieving this goal." }\end{array}$ \\
\hline $\begin{array}{l}\text { Client } \\
\text { meaninglessness }\end{array}$ & $\begin{array}{l}\text { The professionals' perceptions of the added value of } \\
\text { their implementing a policy for their own clients. }\end{array}$ & $\begin{array}{l}\text { A professional noting that a particular policy seriously } \\
\text { impinges on their clients' privacy. }\end{array}$ \\
\hline
\end{tabular}

What value is added by using the policy alienation concept? First, the policy alienation concept adds to the literature by framing the experiences of public professionals with new policies in a coherent theoretical framework. Indeed, although some prominent policy implementation scholars have emphasized the crucial role of committed implementers (Ewalt \& Jennings, 2004; May \& Winter, 2009), few have developed and tested a framework for analyzing this topic (O'Toole, 2000). Further, studies on professions and professionalism (Eraut, 1994; Evetts, 2003; Freidson, 2001; Noordegraaf, 2007) have been insightful on the reactions of professionals to change. However, these studies have not focussed specifically on experiences with public policies. Hence, the policy alienation framework is innovative by providing a coherent theoretical framework for understanding the attitudes of public professionals towards policies. Second, it is one of the few concepts used in the debate on the experiences of professionals with NPM policies that has been quantified using a psychometrically sound approach (DeVellis, 2003; Tummers, 2009). As such, it is wellmatched to the goal of quantitatively examining factors that influence the willingness of public professionals to implement new policies.

\subsection{Policy alienation and related concepts}

Having conceptualized policy alienation, we can now indicate how it differs from a number of related concepts: work alienation, professionalism, autonomy and role conflicts.

First, policy alienation has similarities with, but also differs from, the work alienation concept. One similarity is that policy alienation research, as with most work alienation 
research, focuses on alienation as perceived by the worker (Kanungo, 1982:19). An important difference is that it looks at alienation from the policy being implemented, rather than from the job being done. Secondly, it focuses on the public sector, whereas the work alienation concept was primarily developed for the private sector. This is, for example, shown by the dimension societal meaninglessness, which examines a policy's perceived added value for societal goals.

Second, the concept of policy alienation also differs from 'professionalism'. Indeed, professionalism can be considered as a possible factor influencing certain dimensions of policy alienation (see also Tummers et al., forthcoming 2011). This can be illustrated by looking at two indicators of professionalism: a strong professional association and a high status profession (Eraut, 1994). Looking at professional associations, it is argued that they can legitimize change by hosting a process of discourse through which change is debated and endorsed (Greenwood et al., 2002). If professional associations are sufficiently powerful, they can significantly influence policies. Conversely, when professional associations are not considered crucial for the implementation process, they could be bypassed by policy developers. As a result, professionals might feel powerless on the strategic level and, because of this, will be alienated from the policy. Therefore, stronger professional associations have the potential to decrease the strategic powerlessness of public professionals. Further, the status of a profession can influence policy alienation. Professions with a lower status - such as school teachers and social workers - have greater difficulty in retaining some discretion when implementing a policy. Bucher and Stelling (1969:4) argue that 'the reward [for professional status] is autonomy and influence: the group is accorded the competence to define problems, determine solutions and monitor the functioning of the system.' Therefore, we would expect public professionals to experience less policy alienation when the status of their profession is higher.

Third, policy alienation differs from the notion of professional autonomy or, more specifically, from discretion (Lipsky 1980). Discretion is one of the sub-dimensions of policy alienation, and the counterpart of operational powerlessness. If one was to plot operational powerlessness on a continuum, full discretion would be at one extreme and full operational powerlessness at the other.

Finally, policy alienation is also distinct from the role conflict concept. When implementing a policy, professionals will experience demands based on various logics, such as the logic of their manager, of their clients and of the policy. These logics all have different values, and role conflicts will arise when professionals perceive these logics as incompatible. Role conflicts can best be seen as an effect of a number of the dimensions of policy alienation (Morgeson \& Humphrey, 2008; Organ \& Greene, 1981). 


\subsection{Policy alienation and change willingness}

We can now examine the expected relationship between the various policy alienation dimensions and change willingness.

\section{Powerlessness and change willingness}

When change management scholars examine powerlessness, they often use related concepts such as influence, power and participation (Bouma, 2009). It is well-established that an increase in employee influence on change decisions - or reduced powerlessness leads to increased commitment and performance, and reduces resistance to change (Wanberg \& Banas, 2000). The mechanism which relates influence to change willingness can be traced back to the human relations movement (McGregor, 1960). Examples of this relationship abound. For instance, Sagie and Koslowsky (1994) reported on influence in decision-making being positively related to acceptance among individual employees from five Israeli public organizations. Judson (1991) went as far as to state that involving employees is perhaps the most powerful lever that management can use to gain acceptance of change.

We can apply these findings in relating the powerlessness dimensions to change willingness. Looking at strategic powerlessness, we would expect that the more public professionals - as a professional group - experience an influence in the drafting of a policy, the more they will be willing to implement it. Here, the individual public professionals do not have to experience this influence directly, they can sense an influence if others, such as their professional associations, appear to have fruitfully represented them in the debate. This can lead to an increase in the willingness to implement public policies (Bouma, 2009; Greenwood et al., 2002; Wagner III, 1994). As such, this dimension often concerns indirect, rather than direct, power.

However, an observation should be made here. In the literature on the sociology of professions, there are arguments about re-stratification within professions. Freidson (1994:9) describes re-stratification as follows 'Professionalism is being reborn in a hierarchical form in which everyday practitioners become subject to the control of professional elites who continue to exercise the considerable technical, administrative, and cultural authority that professions have had in the past'. Hence, everyday professionals are different and disconnected from the professional elites, who represent them in their associations. When professional associations or other elite groupings have influence on a strategic level, this might not increase the willingness of the 'everyday' professionals to implement a policy programme. This means that the hypothesis developed above - that less strategic powerlessness leads to a greater willingness to implement a policy programme - might not hold. We will review if this is the case in our empirical analysis. 
The tactical level is most closely related to mainstream change management literature. Here, it is expected that the more professionals experience that they cannot influence the way the policy is implemented within their organization, the less they will be willing to implement the new policy. This influence might be both direct and indirect. Direct participation takes place, for instance, when a professional belongs to a working group set up to help determine organizational rules to match a new policy, or when a professional informally influences executives responsible for an implementation. Indirectly, professionals can feel powerful when colleagues represent them and influence the way that the policy is implemented in their organization.

Finally, greater operational powerlessness - or less discretion - is also expected to be negatively related to change willingness. In the policy implementation literature, it is suggested that an important factor in the attitudes of street-level public servants is the extent to which organizations delegate decision-making authority to the frontline (Meier \& O'Toole, 2002). This influence may be particularly pronounced in professionals whose expectations of discretion and autonomy contradict notions of bureaucratic control (DeHart-Davis \& Pandey, 2005).

To sum up, it is hypothesized that:

$\mathrm{H} 1$ : Strategic powerlessness will be negatively related to change willingness.

$\mathrm{H} 2$ : Tactical powerlessness will be negatively related to change willingness.

H3: Operational powerlessness will be negatively related to change willingness.

\section{Meaninglessness and change willingness}

In the change management literature, the notion of 'case for change' is closely related to the meaninglessness concept. In both theory and practice, it is often noted that a case for change has to be vehemently made if it is to increase change willingness (Armenakis \& Bedeian, 1999). This case for change can stress that there are better ways of doing things better for the organization, better for the employees and better for customers. Developing a case for change is often an important step in planned change approaches. For instance, Higgs and Rowland (2005:127) note that creating a case for change is the first area of leadership competency to be associated with successful change implementation. If employees agree that a change has good and necessary objectives, they should be more supportive of this change.

We can use these findings in relating the meaninglessness dimensions to change willingness. A clear case for change has to be made which stresses a) the contribution of the policy to society (on the societal level) and b) the contribution of the policy to the clients of the professionals (on the client level). 
First, we would expect that the greater the societal meaninglessness that public professionals experience, the less they will be willing to implement a policy. When professionals perceive high societal meaninglessness, they are sensing that a policy programme is not actually dealing with the provision of desirable public services, such as financial protection and security. As a result, they might wonder why they have to implement such a policy. That is, the case for change on the societal level is unclear to them. This may lead them to resist the new policy, and exhibit a low change willingness (Armenakis \& Bedeian, 1999).

Second, greater client meaninglessness is also expected to negatively influence willingness to change. May and Winter (2009) found that if frontline workers perceive the instruments they have at their disposal for implementing a policy as ineffective, in terms of delivering to their clients, this is likely to add to their frustrations. They do not see how their implementation of the policy helps their clients, and so wonder why they should implement it. Given that the evaluation of effectiveness is likely to be based on on-the-job experience, rooted in the circumstances that professionals encounter in doing their job, this aspect of attitude is likely to be particularly important when it comes to determining attitudes and behaviours (Meyers \& Vorsanger, 2003).

Overall, it is hypothesized that:

$\mathrm{H} 4$ : Societal meaninglessness will be negatively related to change willingness.

$\mathrm{H} 5$ : Client meaninglessness will be negatively related to change willingness.

\subsection{The proposed theoretical model}

Figure 1 shows the overall theoretical model representing the hypotheses developed above. In the following sections, we present the methodology for testing this model and our empirical results. 


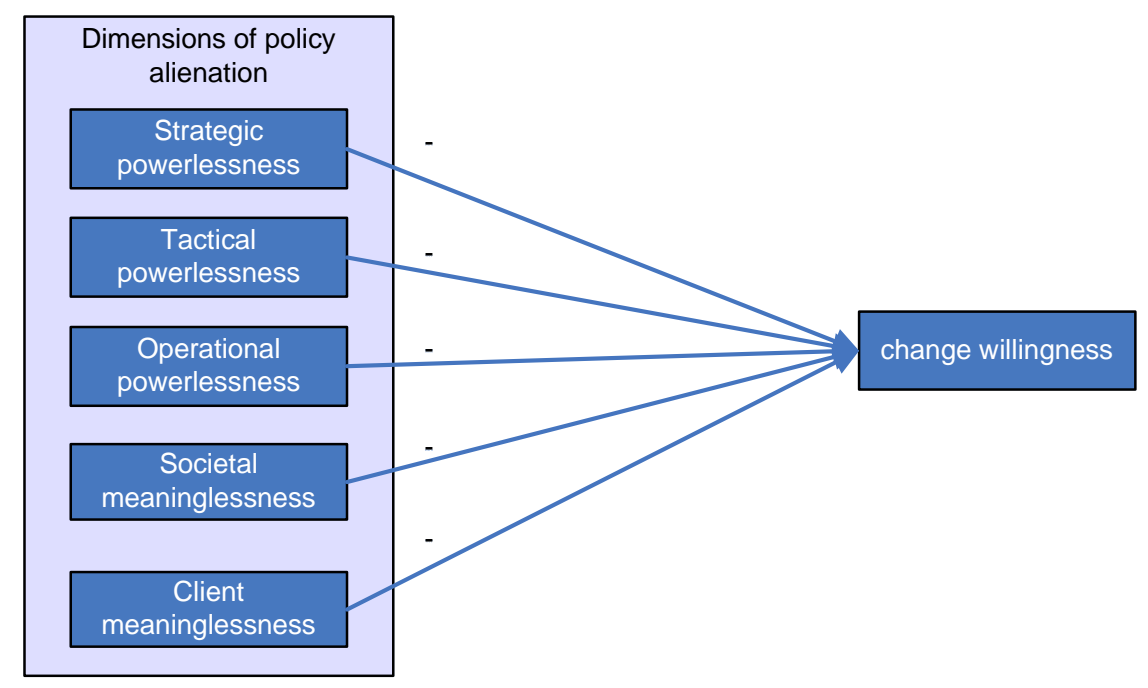

Figure 1 The proposed theoretical model

\section{Method}

\subsection{Testing the proposed model using the DTC policy}

To test the proposed model, we undertook a survey of Dutch mental healthcare professionals implementing a new reimbursement policy. First, we provide a short overview of this policy.

In January 2008, the Health Insurance Law was introduced in the Netherlands. This was part of a process to convert the Dutch healthcare system into one based on a regulated market. In the Health Insurance Law, a system of Diagnosis Treatment Combinations (DTCs) was developed as a means of determining the level of financial reward for mental healthcare provision. The DTC policy differs significantly from the former method, in which each medical action resulted in a financial claim, i.e. the more sessions that a mental healthcare specialist had with a patient, the more recompense that could be claimed. According to some standpoints, this could lead to inefficiencies (Kimberly et al., 2009). The DTC policy changed the situation by stipulating a standard rate for each disorder. The new Health Insurance Law and the associated DTCs can be seen as the introduction of regulated competition into Dutch healthcare, a move in line with NPM ideas. More specifically, it can be seen as a shift to greater competition and more efficient resource use (Hood, 1991:5).

We chose the DTC policy as the basis for testing our model for three reasons. Firstly, public professionals, here psychotherapists, psychologists and psychiatrists, will be the ones implementing the policy, and this is an essential aspect as the model concept is designed to further the debate on the experiences of public professionals with NPM policies. Secondly, the DTC policy focuses strongly on economic goals, such as efficiency and client choice (Helderman et al., 2005), and earlier research on the sociology of professions indicates that it is policies which pursue these kinds of NPM goals that create problems for professionals. As 
such, this policy fits the research problem in hand. Thirdly, in numerous countries, there have been moves towards similar healthcare payment systems. In the early 1980s, Diagnostic Related Groups (DRGs) were developed in the USA to calculate cost prices for health 'products'. Since then, variants of the DRG system have been developed in Australia, Germany, England, Japan, Sweden, Belgium and the Netherlands (Kimberly et al., 2009). This increases the possibility of generalizing the results of the analysis.

\subsection{Sampling and response}

We used a sample of 1800 mental healthcare professionals, randomly selected from the databases of two nationwide mental healthcare associations. We received 478 full or partial returns of our questionnaire. Of those who did not complete the survey, 204 provided reasons. The majority (157) did not work with DTCs for various reasons, such as DTCs were not yet implemented in their organisation, or because their particular profession, such as primary healthcare, did not use DTCs. The next most frequent reason offered was that they had retired or changed occupation (given by 17 respondents). The overall response rate was thus $29 \%$.

Of the valid respondents, $138(29 \%)$ were men and 340 (71\%) women. This balance is consistent with Dutch averages for mental health care professionals, where one can find figures as high as $69 \%$ of the workforce being women (Palm et al., 2008). The respondents' ages ranged from 23 to 90 years $(M=48)$, which is a slightly older average than the Dutch national average for mental healthcare professionals $(M=44)$. Hence, the respondents mean age and gender-distribution are similar to those of the overall mental healthcare sector. Nevertheless, no matter how similar the respondents appear to the population in terms of demographic variables, we cannot rule out a possible non-response bias since the nonrespondents may differ in terms of numerous other characteristics from the respondents. Finally, we found that the educational level was very high: $21 \%$ having studied at an academic level (a bachelor's degree) and 79\% having undertaken postgraduate level training or education (PhD or a specialisation). This is a clear indicator that we have indeed sampled professionals who, in general, have a high educational level (Freidson, 2001).

\subsection{Measures}

\section{Constructing scales for policy alienation}

To be able to measure the identified dimensions of policy alienation, we followed four main steps (for an elaborated discussion on scale development see Tummers, 2009).

First, for each dimension, ten items were generated. These were formatted using fivepoint Likert scales, with allowable responses ranging from strongly disagree to strongly 
agree. We used templates in constructing these items. Templates allow the researcher to specify an item by replacing general phrases with more specific ones that better fit the research context. For example, instead of stating 'the policy' or 'professionals', the researcher can rephrase these items using the specific policy and group of professionals which are being examined, here 'the DTC policy' and 'mental healthcare professionals' replaced the template terms. This makes it easier for professionals to understand items, as they are better tailored to their context and this, in turn, increases reliability and content validity (DeVellis, 2003:62).

Second, to further increase content validity, twenty-one experts examined the initial pool of potential items. These experts were selected for their range of different expertise, including for example quantitative methodologists and mental healthcare specialists (DeVellis, 2003:75). After each expert discussion, we added or discarded certain items based on comments received. At the end of this process, we ended with what can be seen as the six most appropriate items for each dimension. Harvey et al. (1985 in Hinkin, 1998) recommend having at least four items for each scale so that one can test the homogeneity of the items within each latent construct.

We included the items developed in the second step in our survey. After conducting the survey, we then used principle components analysis with an oblique rotation to identify groups of items. Based on this analysis, we chose the best-fitting items for each dimension of policy alienation. The resulting scales are shown in the Appendix and discussed below.

Fourthly, we conducted tests to establish the construct validity of the policy alienation scales. Construct validity is "the extent to which a measure "behaves" the way that its construct it purports to measure should behave with regard to established measures of other constructs' (DeVellis, 2003:53). First, we examined the convergent validity (one form of construct validity): seeking evidence of similarity between measures of theoretically-related constructs. The convergent validity tests show that policy alienation behaves as expected from theory. It correlates significantly and in the expected direction with measures to which it is theoretically related, such as change willingness $(r=-.59, p<.01)$, job satisfaction $(r=-.18$, $p<.01)$ and role conflicts $(r=.60, p<.01)$. Second, we looked at the discriminant validity (another type of construct validity): the absence of correlation between measures of presumed unrelated constructs. The discriminant validity tests show that policy alienation does not correlate with those measures it was not expected to strongly correlate with, such as gender (-.05, n.s.), the number of people working in the institution (.06, n.s.) and working as a freelance or in an institution (.01, n.s.). Given the satisfactory construct validity tests, we can be more confident that we really are measuring policy alienation with this measurement method. 


\section{Powerlessness}

Strategic powerlessness was measured using three items, which sought to elicit information about the perceived influence of the professionals on decisions concerning the content of the policy, as is captured in rules and regulations. A sample items on the scale was 'In my opinion, mental healthcare professionals had too little power to influence the DTC policy'. The results from the present study had a Cronbach's alpha of .74.

Tactical powerlessness was assessed using a six-item scale. These items tap into a professional's perceived influence on decisions concerning the way the DTC policy was implemented in their institution. A sample items was 'In my institution, especially mental healthcare professionals could decide how the DTC policy was implemented (R: reverse item)'. This scale's Cronbach alpha was .86.

Operational powerlessness looks at the discretion of a professional while implementing a policy (Lipsky, 1980). A sample items was 'When I work with DTCs, I have to adhere to tight procedures'. The scale used had six items and a Cronbach alpha of .82.

\section{Meaninglessness}

Societal meaninglessness reflects the perceptions of professionals concerning the added value of a policy to socially relevant goals. Based on expert interviews, we concluded that DTCs had three main goals: 1 . increasing transparency in costs and quality of mental health care, 2. increasing efficiency and, finally, 3. increasing patient choice among mental healthcare providers. Sample items were 'I think that the DTC policy, in the long term, will lead to transparency in the costs of healthcare' $(\mathrm{R})$ and 'Overall, I think that the DTC regulations lead to greater efficiency in mental healthcare' $(R)$. The Cronbach alpha of this scale was .95 .

Client meaninglessness here refers to the perceptions of professionals about the added value of them implementing the DTC policy for their own clients. For instance, do they perceive that they are really helping their patients by implementing this policy? A sample items was 'The DTC policy is contributing to the welfare of my patients' (R). The Cronbach alpha of this scale was .91 .

\section{Change willingness}

We measured change willingness using a validated five-item scale which has shown good reliability (Metselaar, 1997). This scale uses templates in which one can specify the change being assessed. As such, sample items are: 'I am willing to contribute to the introduction of DTCs' and 'I am willing to free up time to implement the DTC policy'. The scale's Cronbach's alpha was .85. 


\section{Control variables}

Alongside the variables described above, we included commonly used control variables in our regression: gender, age, occupation and management position (yes/no). That is, any differences due to these variables are controlled for in the analyses.

\section{Results}

\subsection{Descriptive statistics}

Descriptive statistics and correlations of the variables are presented in Table 2:

Table 2 Descriptive statistics and correlations for the variables in the study

\begin{tabular}{|c|c|c|c|c|c|c|c|c|c|c|c|c|c|c|}
\hline Variable & Mean & SD & 1 & 2 & 3 & 4 & 5 & 6 & 7 & 8 & 9 & 10 & 11 & 12 \\
\hline 1. Sex & 0.71 & 0.46 & & & & & & & & & & & & \\
\hline 2. Age & 47.97 & 10.89 & $-.24^{\star \star}$ & & & & & & & & & & & \\
\hline $\begin{array}{l}\text { 3. Occupation } \\
\text { researcher }\end{array}$ & 0.04 & 0.19 & -.04 & $-.24^{\star \star}$ & & & & & & & & & & \\
\hline $\begin{array}{l}\text { 4. Occupation } \\
\text { psychologist }\end{array}$ & 0.74 & 0.44 & $.19^{\star *}$ & -.07 & $-.31^{* *}$ & & & & & & & & & \\
\hline $\begin{array}{l}\text { 5. Occupation. } \\
\text { psychotherapist }\end{array}$ & 0.45 & 0.50 & -.05 & $.43^{\star \star}$ & $-.18^{* *}$ & $.16^{* *}$ & & & & & & & & \\
\hline $\begin{array}{l}\text { 6. Occupation. } \\
\text { psychiatrist }\end{array}$ & 0.17 & 0.37 & $-.22^{* *}$ & $.12^{*}$ & -.06 & $-.74^{\star *}$ & $-.28^{* *}$ & & & & & & & \\
\hline $\begin{array}{l}\text { 7. Management } \\
\text { position }\end{array}$ & 0.27 & 0.45 & $-.17^{\star *}$ & .09 & -.07 & $-.19^{\star *}$ & $-.10^{*}$ & $.29^{* *}$ & & & & & & \\
\hline $\begin{array}{l}\text { 8. Strategic } \\
\text { powerlessness }\end{array}$ & 3.75 & 0.82 & .01 & $.15^{\star *}$ & -.08 & .01 & $.24^{* *}$ & -.02 & .03 & & & & & \\
\hline $\begin{array}{l}\text { 9. Tactical } \\
\text { powerlessness }\end{array}$ & 3.60 & 0.78 & .06 & $.16^{\star *}$ & -.07 & .08 & $.18^{\star *}$ & -.03 & -.07 & $.38^{\star *}$ & & & & \\
\hline $\begin{array}{l}\text { 10. Operational } \\
\text { powerlessness }\end{array}$ & 3.48 & 0.77 & .01 & .01 & .08 & -.06 & .01 & .05 & -.01 & $.29^{* *}$ & $.33^{\star *}$ & & & \\
\hline $\begin{array}{l}\text { 11. Societal } \\
\text { meaninglessness }\end{array}$ & 3.84 & 0.72 & -.10 & $.27^{\star *}$ & -.04 & -.08 & $.24^{\star *}$ & $.14^{* *}$ & .03 & $.23^{* *}$ & $.26^{\star \star}$ & $.35^{\star *}$ & & \\
\hline $\begin{array}{l}\text { 12. Operational } \\
\text { meaninglessness }\end{array}$ & 4.28 & 0.71 & $-.10^{*}$ & $.15^{\star *}$ & .00 & -.01 & $.12^{*}$ & .09 & .02 & $.24^{\star *}$ & $.24^{* *}$ & $.37^{\star *}$ & $.67^{\star *}$ & \\
\hline $\begin{array}{l}\text { 13. Change } \\
\text { willingness }\end{array}$ & 2.53 & 0.81 & $.13^{*}$ & $-.18^{\star *}$ & -.04 & .08 & -.09 & $-.14^{* \star}$ & .08 & $-.21^{* *}$ & $-.25^{\star *}$ & $-.38^{* *}$ & $-.59^{* *}$ & $-.51^{* *}$ \\
\hline
\end{tabular}

Note. ${ }^{*} p<.05,{ }^{* \star} p<.01$

As can be seen in Table 2, all bivariate correlations for the variables linked through our hypotheses were statistically significant and in the anticipated direction. For example, change willingness was negatively related to strategic powerlessness.

Self-reported data based on a single application of a questionnaire can result in inflated relationships between variables due to common method variance, i.e. variance that is due to the measurement method rather than the constructs themselves (Podsakoff \& Organ, 1986). We conducted a Harman one-factor test to evaluate the extent to which common method 
variance was a concern. A factor analysis was conducted on all 46 items used to measure the variables covered by the hypotheses. The factors together accounted for $70 \%$ of the total variance (using the 'eigenvalue $>1$ ' criterion). The most significant factor did not account for a majority of the variance (only $32 \%$ ). Given that no single factor emerged and the first factor did not account for a majority of the variance, common method variance does not seem to be a major concern here.

\subsection{Regression results}

Hierarchical multiple regression analyses were conducted to examine the extent to which the various dimensions of policy alienation were able to predict change willingness. In the first model, we regressed change willingness onto the control variables. In the subsequent models, we added strategic powerlessness (model 2), tactical powerlessness (model 3), operational powerlessness (model 4), societal meaninglessness (model 5) and client meaninglessness (model 6). In each step, the change in $\mathrm{R}^{2}$ is calculated, and we determine whether each change is significantly different from zero. In the first model, with only control variables in the equation, the $R^{2}$ was $.07(F=3.89, p<.01)$. Adding strategic powerlessness scores in the second model increased $\mathrm{R}^{2}$ to .13 . On inserting the other dimensions in the subsequent models, the $\mathrm{R}^{2}$ increased further, to .41 in model 6 . Thus, the combination of the various dimensions of policy alienation contributed considerably to change willingness as experienced by public professionals. We can now consider the individual hypotheses in more detail.

Hypothesis 1 predicts that the degree of strategic powerlessness experienced by public professionals will be negatively related to their willingness to implement DTCs. As Table 3 shows, when we look at the final model, strategic powerlessness is not significantly related to change willingness. After including the other dimensions of policy alienation, the unique contribution of strategic powerlessness becomes insignificant. That is, this hypothesis was not supported.

Hypothesis 2 predicts that the degree of tactical powerlessness will be negatively related to change willingness. The direct effect of tactical powerlessness on change willingness was insignificant ( $\beta=.04 p=n . s$.). Hence, once again, the results did not support our hypothesis.

The third hypothesis looks at the influence of operational powerlessness on change willingness. As could be expected from the public administration literature, the results indicate that a greater sense of operational powerlessness (or less autonomy) does indeed lower the willingness to change $(\beta=-.15 p<.01)$.

Hypothesis 4 examines the influence of societal meaninglessness on change willingness. In our empirical analysis, this relationship is strong $(\beta=-.39 p<.01)$. That is, when 
professionals do not see a value in a policy in terms of achieving relevant social goals, they are less willing to implement it.

Lastly, Hypothesis 5 looks at the relationship between client meaninglessness and change willingness. The empirical results support the hypothesised relationship: if public professionals feel that a policy does not add value for their clients, they are less inclined to put effort into its implementation $(\beta=-.16 p<.01)$. Table 3 Hierarchical regression analyses for variables predicting change willingness.

\begin{tabular}{|c|c|c|c|c|c|c|}
\hline & $\begin{array}{l}\text { Model } 1 \text { - } \\
\text { Including } \\
\text { control } \\
\text { variables }\end{array}$ & $\begin{array}{l}\text { Model } 2 \text { - } \\
\text { Including } \\
\text { strategic } \\
\text { powerlessness }\end{array}$ & $\begin{array}{l}\text { Model } 3 \text { - } \\
\text { Including } \\
\text { tactical } \\
\text { powerlessness }\end{array}$ & $\begin{array}{l}\text { Model } 4 \text { - } \\
\text { Including } \\
\text { operational } \\
\text { powerlessness }\end{array}$ & $\begin{array}{l}\text { Model 5- } \\
\text { Including } \\
\text { societal } \\
\text { meaningless- } \\
\text { ness }\end{array}$ & $\begin{array}{l}\text { Model } 6 \text { - } \\
\text { Including client } \\
\text { meaningless- } \\
\text { ness }\end{array}$ \\
\hline Female & .07 & .08 & .09 & .09 & .08 & .07 \\
\hline Male & Ref.cat. & Ref.cat. & Ref.cat. & Ref.cat. & Ref.cat. & Ref.cat. \\
\hline Age & $-.15^{\star}$ & $-.14^{\star}$ & -.12 & $-.14^{\star}$ & -.07 & -.07 \\
\hline $\begin{array}{l}\text { Occupation } \\
\text { researcher }\end{array}$ & $-.17^{\star}$ & $-.17^{\star}$ & $-.16^{\star}$ & $-.13^{\star}$ & -.09 & -.08 \\
\hline $\begin{array}{l}\text { Occupation } \\
\text { psychologist }\end{array}$ & -.19 & -.19 & -.16 & -.17 & -.10 & -.08 \\
\hline $\begin{array}{l}\text { Occupation } \\
\text { psychotherapist }\end{array}$ & -.10 & -.05 & -.03 & -.05 & -.06 & .05 \\
\hline $\begin{array}{l}\text { Occupation } \\
\text { psychiatrist }\end{array}$ & $-.32^{\star \star}$ & $-.31^{\star \star}$ & $-.29^{\star \star}$ & $-.28^{\star \star}$ & -.14 & -.12 \\
\hline Managing position & $.14^{\star}$ & $.14^{\star}$ & $.13^{\star}$ & $.13^{\star}$ & $.12^{*}$ & $.12^{\star \star}$ \\
\hline $\begin{array}{l}\text { Non-management } \\
\text { position }\end{array}$ & Ref.cat. & Ref.cat. & Ref.cat. & Ref.cat. & Ref.cat. & Ref.cat. \\
\hline $\begin{array}{l}\text { Strategic } \\
\text { powerlessness }\end{array}$ & & $-.20^{\star \star}$ & $-.14^{\star}$ & -.08 & -.06 & -.04 \\
\hline $\begin{array}{l}\text { Tactical } \\
\text { powerlessness }\end{array}$ & & & $-.17^{\star \star}$ & -.09 & -.04 & -.04 \\
\hline $\begin{array}{l}\text { Operational } \\
\text { powerlessness }\end{array}$ & & & & $-.31^{\star *}$ & $-.17^{\star \star}$ & $-.15^{\star \star}$ \\
\hline $\begin{array}{l}\text { Societal } \\
\text { meaninglessness }\end{array}$ & & & & & $-.49^{\star \star}$ & $-.39^{\star \star}$ \\
\hline $\begin{array}{l}\text { Client } \\
\text { meaninglessness }\end{array}$ & & & & & & $-.16^{\star \star}$ \\
\hline$\Delta \mathrm{R}^{2}$ & & .04 & .02 & .08 & .18 & .01 \\
\hline $\mathrm{F}$ for $\Delta \mathrm{R}^{2}$ & & $11.75^{\star *}$ & $7.56^{\star \star}$ & $28.70^{\star *}$ & $78.39^{\star *}$ & $5.69^{* *}$ \\
\hline Overall $R^{2}$ & .09 & .12 & .14 & .23 & .40 & .41 \\
\hline Overall F & $3.89^{\star *}$ & $4.99^{* *}$ & $5.39^{* *}$ & $8.22^{* *}$ & $16.79^{\star *}$ & $16.14^{\star \star}$ \\
\hline \multicolumn{7}{|c|}{ Note: Standardized beta coefficients are presented. ${ }^{*} p<.05^{* *} p<.01$} \\
\hline $\begin{array}{l}\text { Criterion of indeper } \\
\text { and average close } \\
\text { standardized residu }\end{array}$ & $\begin{array}{l}\text { ent residuals } \\
\text { 1). No exclu } \\
>|2| \text {, Cook's }\end{array}$ & $\begin{array}{l}\text { (Durbin-Watson } 2 \\
\text { ion of influential } \\
\text { distance max. } 0.0\end{array}$ & $\begin{array}{l}<\text { criterion }<3 \text { ). Crit } \\
\text { lying cases was } r \\
(\text { criterion }<1) . \text { Cri }\end{array}$ & $\begin{array}{l}\text { ion of no multico } \\
\text { uired (using case } \\
\text { ia of homosceda }\end{array}$ & $\begin{array}{l}\text { earity (No VIF V } \\
\text { se diagnostics: } \\
\text { sity and normal }\end{array}$ & $\begin{array}{l}\text { es above } 10 \\
\% \text { above } \\
\text { net. }\end{array}$ \\
\hline
\end{tabular}




\section{Discussion: study results and limitations}

Our main goal has been to quantitatively examine factors that influence the willingness, or reluctance, of public professionals to implement new policies. Based on literature from the change management and public administration streams, a theoretical model was constructed linking five dimensions of policy alienation to change willingness. This model was tested in a survey of 478 mental healthcare professionals implementing a new reimbursement policy. The model worked adequately in that the policy alienation dimensions, together with conventional control variables, explained over $40 \%$ of the variance in change willingness. The high internal consistency values (Cronbach alphas ranging from .74 to .95) and the satisfaction of regression criteria strengthens the reliability and validity of the study. As such, we can conclude that the quantitative, interdisciplinary, approach worked satisfactorily and adds to the literature on change management in the public sector. Having reached this conclusion, we can now summarize the results of the study, highlight some of the limitations and make consequent suggestions for future research.

Firstly, we examine the results of the study. After hypothesis testing, we can construct Figure 2, showing those relationships which proved significant. We see that greater strategic or tactical powerlessness do not decrease change willingness, unlike greater operational powerlessness (or less autonomy). This means that the more mental healthcare professionals have the feeling that they have little autonomy when implementing the DTC policy, the less supportive they will be towards this policy. The most important factor in explaining change willingness turned out to be societal meaninglessness: the perception of professionals concerning the added value of a policy to socially relevant goals. Further, when professionals have the feeling that the DTC policy is not contributing to the welfare of their own clients, their willingness to implement this policy again decreases. In the concluding section, we will discuss what these results mean for the debate on the experiences of public professionals with NPM policies. 


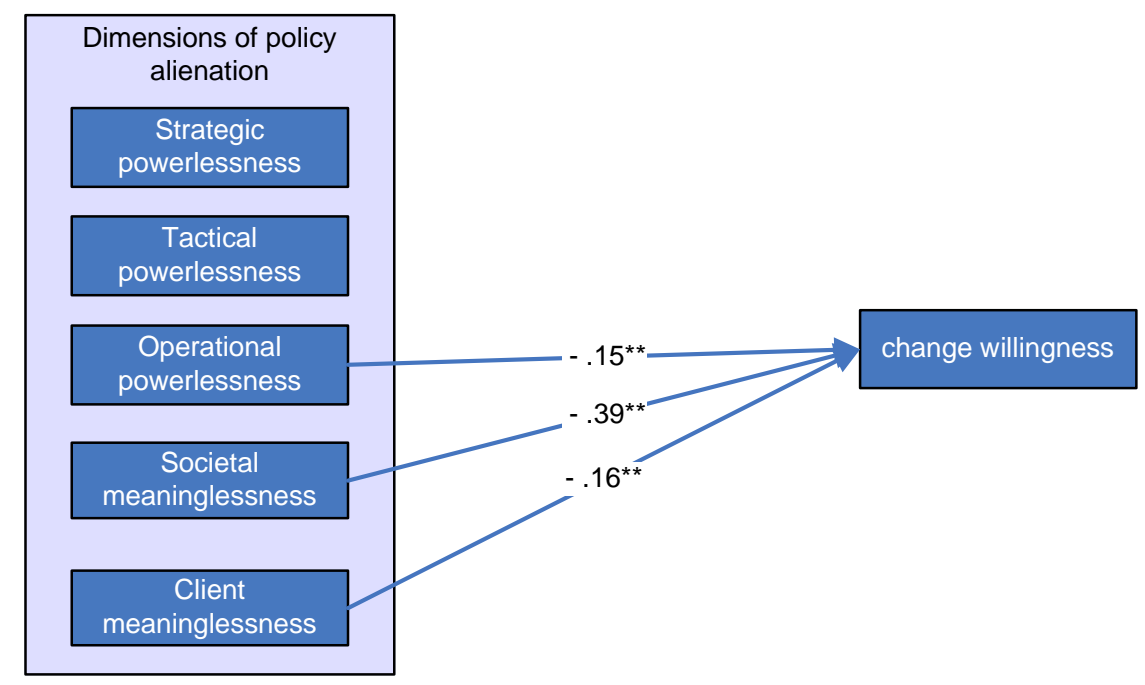

Figure 2 Final model, only paths that achieved significance at the .05 level or better are included

Like all studies, this study has a number of limitations. Here, we discuss two important limitations. Firstly, the results of this study, and the implications outlined, should be interpreted in light of the study's limited context and sample. Although the study's generalizability was improved by the fact that the sample included a large number of public professionals, working in different occupations, positions and places, one should be cautious in generalising this to other public-sector policies or domains. An area for further research would be to test the proposed model using other types of policies in a range of public domains. Here, a comparative approach might work adequately, examining different kinds of policies in various countries.

A second limitation concerns the possible influence of process-related factors, such as the speed of implementation and the way information was shared (how, when, with whom etc.). As noted in the introduction, process-related features are important when studying NPM implementations. Despite this, our cross-sectional quantitative study did not explicitly examine process-related factors. A fruitful direction for future research would therefore be to carry out a longitudinal study that explicitly takes into account - among other factors - the process of policy implementation. Such longitudinal studies are often expensive and complex to manage but they do have the potential to provide fresh insights into how important phenomena, such as professional resistance to the implementation of new policies, develop over time. 


\section{Conclusions}

In the public administration literature, there is an intense debate on the pressures facing public professionals in service delivery. This debate has often looked specifically at the pressures professionals face when implementing NPM policies. Many public professionals are resistant to implementing these policies. In this article, we analyzed factors that influence this (un)willingness to implement public policies. Based on our empirical results, we can draw three conclusions, relevant to both public administration scholars and practitioners.

First, we observed that operational powerlessness strongly influences the willingness to implement new policies. In the public administration literature, such operational power is often referred to as discretion (when applied to street-level public servants) or autonomy (when talking about professionals) (Noordegraaf \& Steijn, forthcoming 2011). Indeed, the notion of autonomy is widely viewed as one of the defining characteristics of professional work. This study is innovative as it quantitatively shows the important role of perceived autonomy during policy implementation. This adds significance to statements in the current debate on pressured professionals, where one sees claims made by leading authors such as Freidson (2001) that the autonomy of professionals is diminishing. Where this is indeed the case, this lowered autonomy could have consequences for the willingness to work with new policies. For policymakers, this means that they should be careful in reducing the autonomy of the public professionals implementing the policy. We are not saying that policymakers should never touch professional autonomy since autonomy may also have substantial disadvantages, such as empire building and inefficiency (Deakin, 1994; Lipsky, 1980). What we are warning is that diminishing the autonomy of professionals should be a deliberate, informed choice, taking account of the possible advantages and disadvantages.

Second, we observed that societal meaninglessness strongly influences willingness to change. Professionals in our survey who felt that the policy did not contribute to the stated goals (such as efficiency and transparency) were far less willing to implement the policy. This is an interesting observation as it contradicts some research on New Public Management which argues that business goals, such as efficiency, are almost by definition not welcomed by professionals (Emery \& Giauque, 2003; Van den Brink et al., 2006). Conversely, in our study, it does not seem that professionals are against these business goals as such. Rather, the mental healthcare professionals were unwilling to implement a policy precisely because it would not achieve the business goals. On the basis of our findings, it is unwarranted to say that public professionals are against business goals as such. They are unwilling to implement an NPM policy not because it focuses on business goals, but because it will not achieve those business goals. For policymakers and change agents implementing policies, this means that efficiency or transparency can indeed be seen as a valuable goal for a new 
policy. Therefore, such policymakers and change agents could more openly state that these are the goals being pursued and, further, they can try to include professionals in debates on how to achieve these goals.

Third, the change willingness of implementing professionals is more dependent on the perceived added value of the policy, for society and for their own clients, than on their own perceived influence on the strategic or tactical levels. This could be an indication that, for public professionals, it is more important to see the logic of a new policy than to have the feeling of being able to influence its shaping. This is an important observation in that increasing perceived influence may not be as 'powerful a lever' as some authors claim (for example Judson, 1991). Further, the non-significant influence of strategic powerlessness can be an indication of the re-stratification thesis, stating that 'everyday' professionals are different and disconnected from the elite representing them in their associations (Freidson, 2001). Overall, influence on strategic and tactical levels does not seem to have a direct effect on willingness to implement a policy, although indirect effects are possible (Bouma, 2009). Rather than focus on these powerlessness aspects, policymakers should centre their attention on the perceived meaninglessness of a policy for society or for the professionals' clients. Policymakers could think about ways to improve the perceived added value of a policy. One way could be to more intensively communicate the values associated with a policy, highlighting its urgency and the desired results. Further, pilots might be initiated before 'rolling out' a policy nationwide. This could improve the effectiveness of a policy, thereby increasing its perceived value.

Concluding, this study provides insights that help to understand why public professionals are reluctant to implement new policies. Embracing and further researching the attitudes of these professionals towards new policies should prove to be a timely and productive endeavour for both researchers and practitioners alike. 


\section{Appendix: Scales for policy alienation}

Table 4 Items on the policy alienation scale

Policy alienation scale (Tummers, 2009)

Template words are underlined

Strategic powerlessness

1. In my opinion, professionals had too little power to influence the policy

2. We professionals were completely powerless during the introduction of the policy

3. Professionals could not at all influence the development of the policy at the national level (Minister and Ministry of $\underline{X}$, National Government)

Tactical powerlessness

4. In my organisation, especially professionals could decide how the policy was being implemented (R)

5. In my organisation, professionals have - by means of working groups or meetings - taken part in decisions on the execution of the policy $(\mathrm{R})$

6. The management of my organisation should have involved the professionals far more in the execution of the policy

7. Professionals were not listened to over the introduction of the policy in my organisation

8. In my organisation, professionals could take part in conversations regarding the execution of the policy (R)

9. I and my fellow professionals were completely powerless in the introduction of the policy in my organisation Operational powerlessness

10. I have freedom to decide how to use the policy $(R)$

11. While working with the policy, I can be in keeping with the client's needs $(R)$

12. Working with the policy feels like a harness in which I cannot easily move

13. When I work with the policy, I have to adhere to tight procedures

14. While working with the policy, I cannot sufficiently tailor it to the needs of my clients

15. While working with the policy, I can make my own judgments (R)

Societal meaninglessness

16. I think that the policy, in the long term, will lead to goal $1(\mathrm{R})$

17. I think that the policy, in the short term, will lead to goal $1(R)$

18. I think that the policy has already led to goal $1(\mathrm{R})$

19. Overall, I think that the policy leads to goal $1(R)$

Client meaninglessness

20. With the policy I can better solve the problems of my clients $(R)$

21. The policy is contributing to the welfare of my clients $(R)$

22. Because of the policy, I can help clients more efficiently than before (R)

23. I think that the policy is ultimately favourable for my clients (R)

The further use of this policy alienation scale for scientific research is permitted, subject to appropriate reference to the author. Conversely, the author would highly appreciate permission to use anonymous data to further validate the scales with other target groups. If you would like to use the scales for commercial purposes, you should first contact the author to seek permission. 
Abbott, A. (1988). The system of the professions. Chicago: The University of Chicago Press.

Ackroyd, S., Kirkpatrick, I., \& Walker, R. M. (2007). Public management reform in the UK and its consequences for professional organization: A comparative analysis. Public Administration, 85(1), 9-26.

Alvesson, M., \& Johansson, A. W. (2002). Professionalism and politics in management consultancy work. In T. Clarke, \& R. Finchham (Eds.), Critical consulting (pp. 228-246). Oxford: Wiley-Blackwell.

Armenakis, A. A., \& Bedeian, A. G. (1999). Organizational change: A review of theory and research in the 1990s. Journal of Management, 25(3), 293.

Blauner, R. (1964). Alienation and freedom. Chicago: University of Chicago Press.

Bouma, J. T. (2009). Why participation works: The role of employee involvement in the implementation of the customer relationship management type of organizational change. Groningen: SOM Research School.

Brandsen, T. (2009). Civicness in organizations: A reflection on the relationship between professionals and managers. Voluntas: International Journal of Voluntary and Nonprofit Organizations, 20(3), 260-273.

Bucher, R., \& Stelling, J. (1969). Characteristics of professional organizations. Journal of Health and Social Behavior, 10(1), 3-15.

Burke, W. W., \& Litwin, G. H. (1992). A causal model of organizational performance and change. Journal of Management, 18(3), 523-545.

Christensen, T., \& Laegreid, P. (2008). NPM and beyond-structure, culture and demography. International Review of Administrative Sciences, 74(1), 7.

De Boer, W., \& Steenbeek, R. (2005). Probleemsituaties en dilemma's in de verzekeringsgeneeskunde.NVVG.

De Ruyter, A., Kirkpatrick, I., Hoque, K., Lonsdale, C., \& Malan, J. (2008). Agency working and the degradation of public service employment: The case of nurses and social workers. The International Journal of Human Resource Management, 19(3), 432-445. 
Deakin, N. (1994). The politics of welfare: Continuities and change. London: Harvester Wheatsheaf.

DeHart-Davis, L., \& Pandey, S. (2005). Red tape and public employees: Does perceived rule dysfunction alienate managers? Journal of Public Administration Research and Theory, 15(1), 133-148.

DeVellis, R. F. (2003). Scale development: Theory and applications. Thousand Oaks: Sage.

Duyvendak, J. W., Knijn, T., \& Kremer, M. (Eds.). (2006). Policy, people, and the new professional. de-professionalisation and re-professionalisation in care and welfare. Amsterdam: Amsterdam University Press.

Easton, D. (1965). A system analysis of political life. London: Wiley.

Emery, Y., \& Giauque, D. (2003). Emergence of contradictory injunctions in swiss NPM projects. International Journal of Public Sector Management, 16(6), 468-481.

Eraut, M. (1994). Developing professional knowledge and competence. London: Routledge.

Evetts, J. (2003). The sociological analysis of professionalism. International Sociology, 18(2), 395-415.

Evetts, J. (2006). Short note: The sociology of professional groups. Current Sociology, 54(1), 133-143.

Ewalt, J. A. G., \& Jennings, E. T. (2004). Administration, governance, and policy tools in welfare policy implementation. Public Administration Review, 64(4), 449-462.

Exworthy, M., \& Halford, S. (Eds.). (1998). Professionals and the new managerialism in the public sector. Maidenhead, UK: Open University Press.

Freidson, E. (1994). Professionalism reborn: Theory, prophecy, and policy. Chicago: University of Chicago Press.

Freidson, E. (2001). Professionalism: The third logic. Cambridge: Cambridge University Press. 
Greenwood, R., Suddaby, R., \& Hinings, C. R. (2002). Theorizing change: The role of professional associations in the transformation of institutionalized fields. The Academy of Management Journal, 45(1), 58-80.

Hanlon, G. (1998). Professionalism as enterprise: Service class politics and the redefinition of professionalism. Sociology, 32(1), 43-63.

Helderman, J. K., Schut, F. T., Van Der Grinten, T. E. D., \& Van De Ven, W. P. M. M. (2005). Market-oriented health care reforms and policy learning in the netherlands. Journal of Health Politics, Policy and Law, 30(1-2), 189-210.

Higgs, M., \& Rowland, D. (2005). All changes great and small: Exploring approaches to change and its leadership. Journal of Change Management, 5(2), 121-151.

Hinkin, T. R. (1998). A brief tutorial on the development of measures for use in survey questionnaires. Organizational Research Methods, 1, 104-121.

Hood, C. (1991). A public management for all seasons. Public Administration, 19(1), 3-19.

Judson, A. S. (1991). Changing behavior in organization: Minimizing resistance to change. Cambridge, MA: Basil Blackwell.

Kanungo, R. N. (1982). Work alienation: An integrative approach. New York: Praeger Publishers.

Kickert, W. J. M. (forthcoming 2011). Managing emergent and complex change: The case of dutch agencification. International Review of Administrative Sciences,

Kimberly, J. R., de Pouvourville, G., \& Thomas, A. D. A. (2009). The globalization of managerial innovation in health care. Cambridge: Cambridge University Press.

Krause, E. A. (1996). Death of the guilds. New Haven: Yale University Press.

Lewin, K. (1951). Field theory in social science New York: Harper.

Lipsky, M. (1980). Street-level bureaucracy. New York: Russell Sage Foundation.

May, P. J., \& Winter, S. C. (2009). Politicians, managers, and street-level bureaucrats: Influences on policy implementation. Journal of Public Administration Research and Theory, 19(3), 453. 
McGregor, D. (1960). The human side of enterprise. New York: Wiley.

Meier, K. J., \& O'Toole, L. J. (2002). Public management and organizational performance: The effect of managerial quality. Journal of Policy Analysis and Management, 21(4), 629643.

Metselaar, E. E. (1997). Assessing the willingness to change: Construction and validation of the DINAMO. (Doctoral dissertation, Free University of Amsterdam).

Meyers, M. K., \& Vorsanger, S. (2003). Street-level bureaucrats and the implementation of public policy. (pp. 245-256). London: Sage.

Morgeson, F. P., \& Humphrey, S. E. (2008). Job and team design: Toward a more integrative conceptualization of work design. Research in Personnel and Human Resource Management, 27, 39-92.

Noordegraaf, M. (2007). From "Pure" to "Hybrid" professionalism: Present-day professionalism in ambiguous public domains. Administration \& Society, 39(6), 761-785.

Noordegraaf, M., \& Steijn, A. J. (Eds.). (forthcoming 2011). Professionals under pressure: Perspectives on professionals and professionalism. Amsterdam: Amsterdam University Press.

Organ, D. W., \& Greene, C. N. (1981). The effects of formalization on professional involvement: A compensatory process approach. Administrative Science Quarterly, 26(2), 237-252.

O'Toole, L. J. (2000). Research on policy implementation: Assessment and prospects. Journal of Public Administration Research and Theory, 10(2), 263-288.

Parsons, T. (1964). The social system. New York: Free Press.

Piderit, S. K. (2000). Rethinking resistance and recognizing ambivalence: A multidimensional view of attitudes toward an organizational change. The Academy of Management Review, 25(4), 783-794.

Podsakoff, P. M., \& Organ, D. W. (1986). Self-reports in organizational research: Problems and prospects. Journal of Management, 12(4), 531-544. 
Pollitt, C., \& Bouckaert, G. (2004). Public management reform. A comparative analysis. Oxford: Oxford University Press.

Raelin, J. A. (1986). The clash of cultures: Managers and professionals. Boston: Harvard Business Press.

Rayce, S. L. B., Holstein, B. E., \& Kreiner, S. (2008). Aspects of alienation and symptom load among adolescents. The European Journal of Public Health, 19(1), 79-84.

Sagie, A., \& Koslowsky, M. (1994). Organizational attitudes and behaviors as a function of participation in strategic and tactical change decisions: An application of path-goal theory. Journal of Organizational Behavior, 15(1), 37-47.

Schön, D. A. (1983). The reflective practitioner. New York: Basic books.

Seeman, M. (1959). On the meaning of alienation. American Sociological Review, 24(6), 783-791.

Stone, D. (2003). . New York: Norton \& Co.

Thomas, R., \& Davies, A. (2005). Theorizing the micro-politics of resistance: New public management and managerial identities in the UK public services. Organization Studies, 26(5), 683-706.

Tummers, L. G. (2009). Policy alienation of public professionals: The development of a scale. Annual Work Conference Netherlands Institute of Government (NIG) (12-13 November), Leiden University: Leiden.

Tummers, L. G., Bekkers, V. J. J. M., \& Steijn, A. J. (2009). Policy alienation of public professionals: Application in a new public management context. Public Management Review, 11(5), 685-706.

Tummers, L. G., Steijn, A. J., \& Bekkers, V. J. J. M. (forthcoming 2011). Pressures professionals experience while implementing policies: Looking beyond new public management. In M. Noordegraaf, \& A. J. Steijn (Eds.), Professionals under pressure: Perspectives on professionals and professionalism (). Amsterdam: Amsterdam University Press. 
Van Bockel, J., \& Noordegraaf, M. (2006). Identifying identities: Performance-driven, but professional public managers. International Journal of Public Sector Management, 19(6), 585-597.

Van den Brink, G., Jansen, T., \& Pessers, D. (2006). Beroepszeer: Waarom nederland niet goed werkt. Amsterdam: Boom.

Van Thiel, S., \& Leeuw, F. L. (2002). The performance paradox in the public sector. Public Performance and Management Review, 25(3), 267-281.

Wagner III, J. A. (1994). Participation's effects on performance and satisfaction: A reconsideration of research evidence. Academy of Management Review, 19(2), 312-330.

Wanberg, C. R., \& Banas, J. T. (2000). Predictors and outcomes of openness to changes in a reorganizing workplace. Journal of Applied Psychology, 85(1), 132-142.

Weick, K. E. (2000). Emergent change as a universal in organizations. In M. Beer, \& N. Nohria (Eds.), Breaking the code of change (pp. 223-241). Boston: Harvard Business School Press.

White, D. (1996). A balancing act: Mental health policy-making in quebec. International Journal of Law and Psychiatry, 19(3-4), 289-307.

Lars Tummers is a PhD-candidate at the Erasmus University of Rotterdam, The Netherlands. His research focuses on the experiences of professionals during changes (such as public management reform). He is especially interested in the experiences of professionals when they implement new policies, examining this using the innovative concept of 'policy alienation'. As well as his scholarly work, Lars is a change management consultant at PwC (PricewaterhouseCoopers), Healthcare. 